\title{
Prevalence and intensity of protozoan ectoparasite of the white leg shrimp ( penaeus indicus ) in Helleh site, South of Iran
}

\author{
S Kakoolaki ${ }^{1}$ and M Afsharnasab ${ }^{1}$ \\ ${ }^{1}$ Iranian Fisheries Science Research Institute,Agricultural Research, Education and Extention Org., Tehran,Iran
}

Recived: May 2015

\begin{abstract}
Development of shrimp farming has been associated with the incidence of fatal diseases including viral, bacterial and protozoan parasites of shrimp. Our study was aimed to present a status of several important protozoan parasites of Litopenaeus van namei in cultured earthen ponds in Iran during the period of 2011-12. One hundred live shrimp were randomly prepared from the Shrimp Helleh Station in south of Iran. Prevalence and intensity were two important indices that calculated in our research. They were scraping, puttingon clean slides and examined under microscope to observe the protozoan parasites. Zoothamnium sp. is more prevalent pathogen among Peritrichous ciliates (79 to 88) in pleopods. Acineta sp. was less prevalent in our isolations neither in pleopods nor in gills. It was concluded that, Peritrichous ciliates are more frequent ciliates causing mortality in cultured shrimps at high density in higher temperature and ammonia.
\end{abstract}

Keywords: Penaeus indicus , protozoan, epibiont ciliates, epicommensal.

\section{Introduction}

In recent decades, Development of shrimp farming has been associated with the incidence of fatal diseases including viral, bacterial and protozoan parasites of shrimp (Lightner 1996). Therefore, shrimp farmers have been suffering from losing the production (Afsharnasab 2012; Kakoolaki, Sharifpour,

Correspondence S Kakoolaki, Agricultural Research, Education and Extension Org., Iranian Fisheries Science Research Institute, Tehran, Iran (e-mail:bsh443@gmail.com)
Accepted: October 2015

Sharifrohani, Ebrahimzadeh Mousavi, Afsharnasab, Hoghoughirad, Dashtiannasab \& Nezamabadi 2013). Shrimp production in Iran is not exempt from these global fluctuations. When shrimp production in 2007 fell by half, the farmers shifted the cultured species from Fenneropenaeus indicus to Litopenaeus vannamei to reach 20,000 tons in 2013 as highest record (Kakoolaki et al. 2013). The exoskeleton of crustaceans provides suitable organic substrates for many species of epibiont ciliates, especially suctorians, chonotrichs, and peritrichs (Mayen-Estrada R. \& Aladro-Lubel M. A. 2002).

Some researchers have reported Peritrichous ciliates parasites such as Zoothamnium sp., Epistylis sp., Acineta sp. and Vorticella sp. in which exoskeleton are the target tissue (Jalali Jafari 1990; Kakoolaki 1997; Tamjidi 1995). Protozoan parasites and commensals occur both inside and outside the host body. Zoothamnim sp. and Vorticella sp. are ecto-parasites and gregarines is endo-parasite (Chakraborti \& Bandyapadhyay 2011). Quantity of Peritrichs can rapidly increase, attach and feed on the exoskeleton and gill tissues due to poor quality of either earthen or hatchery pond water (Jalali Jafari 1990; Kakoolaki 1997). Overstreet (1973) showed that there is a putative relationship between the epibiont ciliate, Zoothamnium sp. and mortality of shrimp following stress. Their abundant presence can interfere with the breathing and mobility of the host (Jayasree, Janakiram \& Madhavi 2001). Zoothamnium sp. are at their peak during climate change and increasing the concentration of nitrite or nitrate and can be controlled by salinity changes or habitat (Jayasree et al. 2001).

Zoothamnium is a frequent inhabitant of the gill surfaces of shrimp in ponds with low oxygen content and heavily infested shrimp can suffocate. Sur- 
face-settling protozoa occasionally cause problems in shrimp hatcheries when larval shrimp become overburdened and arc unable to swim normally. As protozoa continuously multiply in numbers, shrimp acquire anincreasing burden until shedding of the cuticle provides relief. Members of one unique group of protozoa, the apostome ciliates, have a resting stage that will settle on shrimp surfaces. When the crustacean molts, the protozoan releases and completes the life cycle within the shed cuticle before entering the stage on a new crustacean (Johnson 1990).

In this paper, we will attempt to present the status of several important protozoan parasites of shrimp in cultured earthen ponds in Iran.

\section{Materials and Methods}

\section{Sampling}

The present study was done during the period of 2011 to 2012. One hundred live shrimp Litopeneaus vannamei were randomly prepared from the Shrimp Helleh Station in south of Iran. They were transferred to National Shrimp Research Center in Bushehr provinceand then acclimated and reared under the optimum condition of water quality (Kakoolaki, Soltani, Ebrahimzadeh Mousavi, Sharifpour, Mirzargar, Afsharnasab \& Motalebi 2011).

\section{Isolation of pathogens}

Animals were scraping from Exoskeleton and gills were taken on clean slides. The smeared slides were air dried, fixed in acetone free methanol and stained with Giemsa or directly wet smeared. The slides were examined under microscope to observe the protozoan parasites. From the collected data, prevalence and intensity of infection by each species of parasites were determined.

\section{Prevalence and Intensity of infection}

One hundred of shrimp were dedicated for collecting the ecto-parasites to identify the prevalence and intensity of infection.

Prevalence of infection was calculated using following formula:

$\mathrm{P}=\mathrm{N}$ of infected shrimps/ all shrimps in an aquar- ium (Oie 2006)

Where Pis prevalence in an aquarium and $\mathrm{N}$ is number that given as Mean \pm SD.

Intensity of infection was analyzed as follows:(Malolahi A. \& Mokhayer B. 2001)

I= If the number of observed parasites under light microscope were 5-50, 51-100 and more than 100, the intensity named mild, moderate and severe, respectively.

\section{Statistical analysis}

Cross tabulation, accompanying with Kendall's taubwas used to determine the relation between rows and columns with the probability of $95 \%$.

\section{Results}

In cross-tabulation that was made between 2 subgroups of weight (under and above $15 \mathrm{~g}$ ) and 6 groups containing 3 subgroups, only the relation between weight and zoothamnium in pleopods was significant (Kendall's tau-b: .003) and with other groups were not significant ( $p>0.05$ ). Based on the table 1 , it seems $66.7 \%$ of infected pleopods were in the shrimp with the weightof less than $15 \mathrm{~g}$.

In cross-tabulation is given in Table 2, there is a significant relationship (Kendall's tau-b: .026) between the occurrence of Epistylis sp. either in pleopods and gills of infected shrimp. But lesser or absent of severity in gills had significant relation with same protozoa in pleopods. According to the Table 2, it seems Epistylis were observed more in pleopods in comparison to gills. Based on the Table 3, there was a significant relationship (Kendall's tau-b: .048) between the occurrence of Zoothamnium sp. in pleopods and Acineta sp. in gills of infected shrimps. It showed that increasing the incidence of Zoothamnium sp. in pleopods has significant relation with lesser incidence of Acineta sp. of gills.

The prevalences of Zoothamnium sp., Epistylis sp. and Acineta sp. in pleopods were calculated as follows:

$\mathrm{P}($ Zoothamnium sp. $)=79 / 100 \times 100, \mathrm{P}=79 \%$ (n: 100)

$\mathrm{P}($ Epistylis sp. $)=61 / 100 \times 100, \mathrm{P}=61 \%$ (n: 100)

$\mathrm{P}($ Acineta sp. $)=7 / 100 \times 100, \mathrm{P}=2 \%(\mathrm{n}: 100)$

The prevalences of Zoothamnium sp. ,Epistylis sp. 
Iranian Journal of Aquatic Animal Health

Table 1 Cross tabulation between weight groups and Zoothamnium sp. observed on pleopods and gills.

\begin{tabular}{|c|c|c|c|c|c|c|}
\hline \multirow{5}{*}{ Weight grouping } & \multirow{4}{*}{1} & & \multicolumn{3}{|c|}{ PleopodZoothamnium sp. } & \multirow[t]{2}{*}{ Total } \\
\hline & & & Severe & moderate & mild & \\
\hline & & Count & 9 & 8 & 7 & 24 \\
\hline & & $\%$ of Total & $25.0 \%$ & $22.2 \%$ & $19.4 \%$ & $66.7 \%$ \\
\hline & 2 & Count & 9 & 3 & 0 & 12 \\
\hline \multirow{3}{*}{ Total } & & $\%$ of Total & $25.0 \%$ & $8.3 \%$ & $.0 \%$ & $33.3 \%$ \\
\hline & & Count & 18 & 11 & 7 & 36 \\
\hline & & $\%$ of Total & $50.0 \%$ & $30.6 \%$ & $19.4 \%$ & $100.0 \%$ \\
\hline
\end{tabular}

Table 2 Cross tabulation between Epistylis sp. in Pleopod groups and Epistylis sp. observed in Gills.

\begin{tabular}{|c|c|c|c|c|c|}
\hline & & & Epistyli & & Total \\
\hline & & & 3 & 4 & \\
\hline \multirow[t]{6}{*}{ Epistylis in Pleopods } & 1 & Count & 9 & 5 & 14 \\
\hline & & $\%$ of Total & $25.0 \%$ & $13.9 \%$ & $38.9 \%$ \\
\hline & 2 & Count & 8 & 3 & 11 \\
\hline & & $\%$ of Total & $22.2 \%$ & $8.3 \%$ & $30.6 \%$ \\
\hline & 3 & Count & 2 & 9 & 11 \\
\hline & & $\%$ of Total & $5.6 \%$ & $25.0 \%$ & $30.6 \%$ \\
\hline \multirow[t]{2}{*}{ Total } & & Count & 19 & 17 & 36 \\
\hline & & $\%$ of Total & $52.8 \%$ & $47.2 \%$ & $100.0 \%$ \\
\hline
\end{tabular}

Table 3 Cross tabulation between Zoothamnium sp. in Pleopodseverity groups and Acineta sp. severity groups observed in Gills.

\begin{tabular}{|c|c|c|c|c|c|}
\hline & & & \multicolumn{2}{|c|}{ Acineta in gills } & \multirow[t]{2}{*}{ Total } \\
\hline & & & 3 & 4 & \\
\hline \multirow[t]{6}{*}{ Zoothamnium in Pleopods } & Severe & Count & 1 & 17 & 18 \\
\hline & & $\%$ of Total & $2.8 \%$ & $47.2 \%$ & $50.0 \%$ \\
\hline & moderate & Count & 2 & 9 & 11 \\
\hline & & $\%$ of Total & $5.6 \%$ & $25.0 \%$ & $30.6 \%$ \\
\hline & weak & Count & 3 & 4 & 7 \\
\hline & & $\%$ of Total & $8.3 \%$ & $11.1 \%$ & $19.4 \%$ \\
\hline \multirow[t]{2}{*}{ Total } & & Count & 6 & 30 & 36 \\
\hline & & $\%$ of Total & $16.7 \%$ & $83.3 \%$ & $100.0 \%$ \\
\hline
\end{tabular}

and Acineta sp. in gills are given as follows:

$\mathrm{P}($ Zoothamnium sp. $)=12 / 100 \times 100, \mathrm{P}=12 \%$ (n:

100)

$\mathrm{P}$ (Epistylis sp.) $=7 / 100 \times 100, \mathrm{P}=7 \%$ (n: 100)

$\mathrm{P}($ Acineta sp. $)=5 / 100 \times 100, \mathrm{P}=5 \%$ (n: 100$)$

The figures of common and non-common peritrichous ciliates observed in shrimp are given as Tables 1-6. Whole figures show a common stalk for attaching to the host tissue.

\section{Discussion}

Our study was aimed to identify the ecto-parasite species and determined the prevalence and intensity of the infection in Litopenaeus vannamei cultured in Iran. According to the results obtained, the prevalence of Zoothamnium sp. was higher in comparison to Acineta sp. or Epistylis sp. In the other view, the peritrichous ciliates were more common in pleopods but gills. It seems shrimp with lesser weights were more susceptible to Zoothamnium sp. but no significant difference was observed between severities across the groups (Table 1 ).

According to the results of prevalences (Fig. 3), Acineta sp. was less prevalent in our isolations neither in pleopods nor in gills. Based on Table 2, there 


\section{S Kakoolaki et al., Protozoan ectoparasite of white leg shrimp}

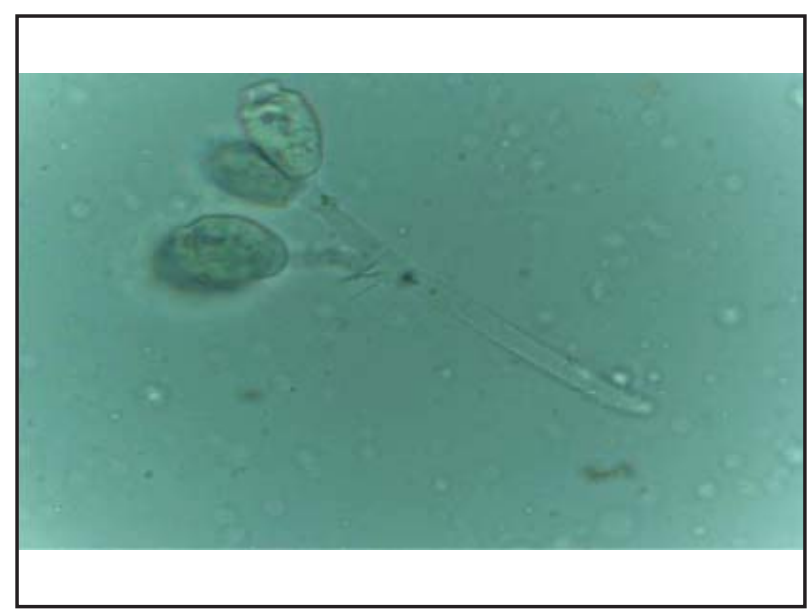

Figure 1 It shows 3 Zoothamnium with 3 individual stalks and 1 common stalk to attach to host tissue; wet mount, $\times 400$.

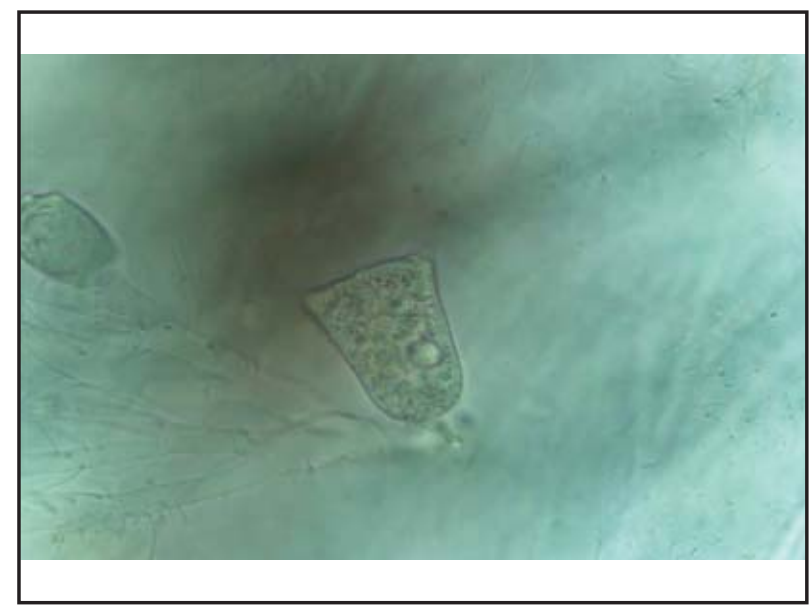

Figure 3 Acineta attached to a host tissue; wet mount, $\times 400$.

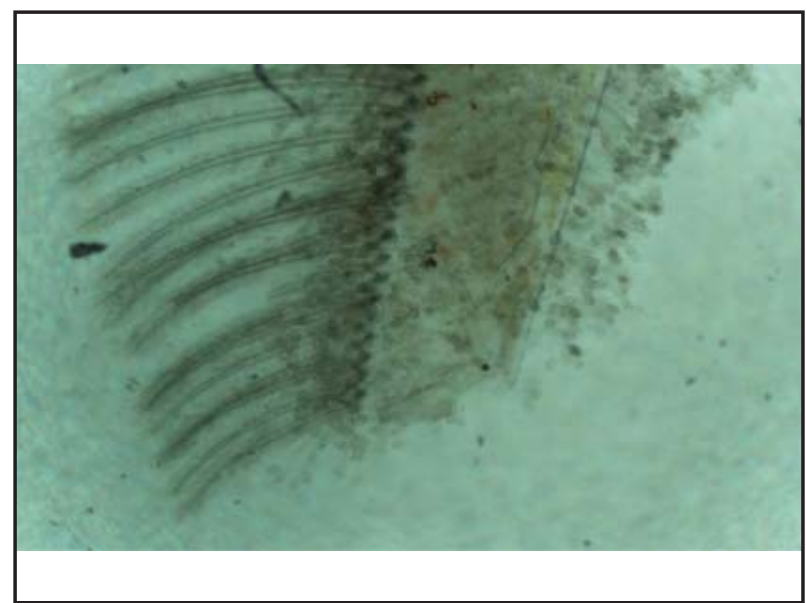

Figure 5 Intensity of attached different parasites to shrimp gill; wet mount, $\times 40$.

is a matched trend between the severity of Zoothamnium sp. in pleopods and gills so that while increasing of the infection became more in pleopods, an increasing trend of the parasite incidence also was

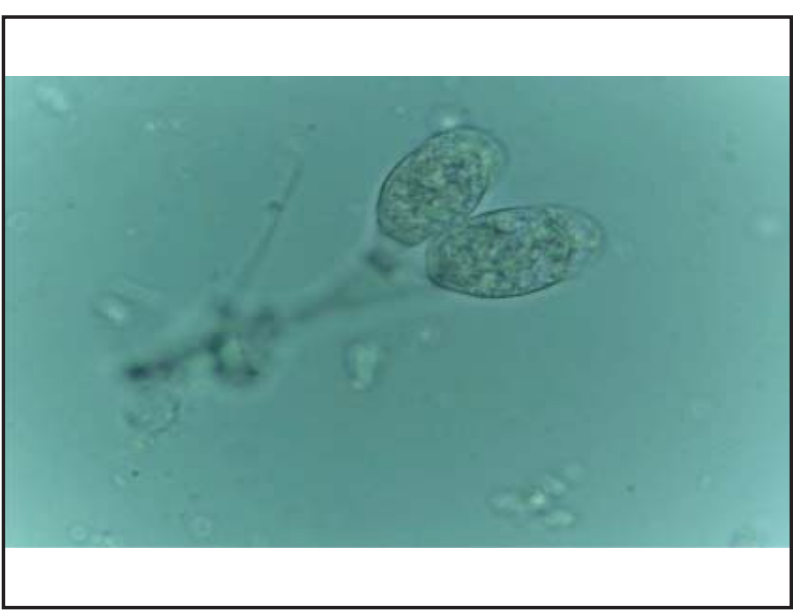

Figure 2 It shows Epistylis with a common stalk to attach to host tissue; wet mount, $\times 400$.

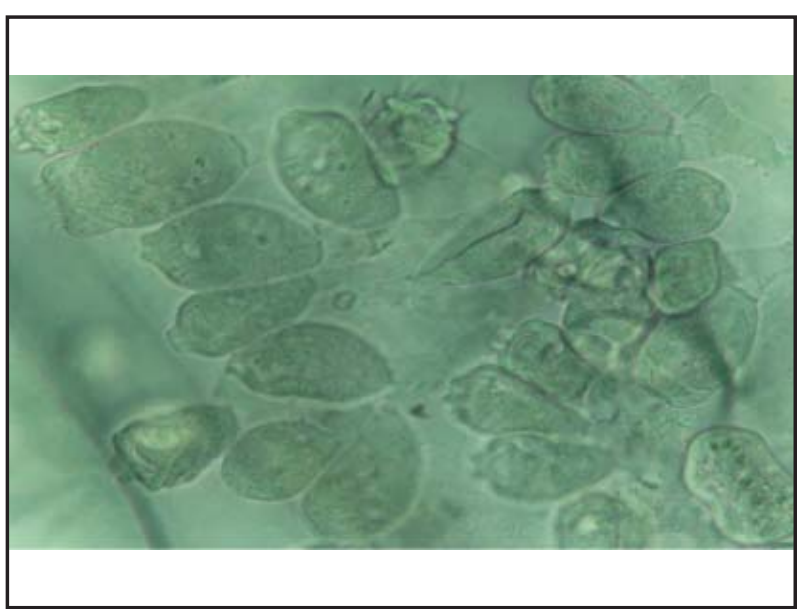

Figure 4 Intensity of attached different parasites to shrimp gill; wet mount, $\times 400$.

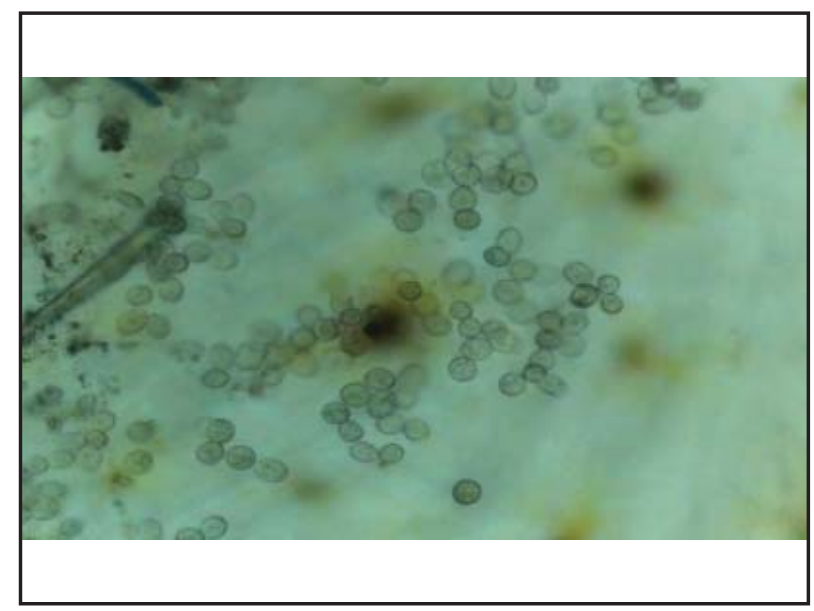

Figure 6 Intensity of attached different parasites to shrimp pleopods; wet mount, $\times 100$.

observed in gills. On the other hand, increasing of severity of Zoothamnium sp. in pleopodswas contrarily matched with Acineta sp. in gills. Similar to the result of Abedian \& Ebrahimi (2006) our results 
showed that Zoothamnium sp. is more prevalent pathogen among peritrichous ciliates (88.66\% to $79 \%$ ) in pleopods. The least value for shrimp ciliated infections belong to Acineta with $2 \%$ of shrimp pleopods. This result is contrary to the result of Abedian \& Ebrahimi (2006) that recorded Vorticella sp. has least prevalence among ciliates (0.24\%). In another survey (Mayen-Estrada R. \& Aladro-Lubel M. A. 2002) Vorticella sp. was the most prevalent peritrichous for crayfish attached to pereiopods and gills. This result is matched to the result of Chakraborti \& Bandyapadhyay (2011) that confirmed Vorticella sp. the most frequent ciliates from tiger shrimp. They showed the infection increase at $29-31^{\circ} \mathrm{C}$ and decrease above or below this degree. Thus, an optimum temperature of $29-31^{\circ} \mathrm{C}$ is required for growth and survival of the protozoan parasites. Since they are epibionts, the infection caused by them at a low density is non pathogenic but heavy infection may cause fouling of gills and appendages. They may even cause death since they interfere with respiration and locomotion (Overstreet 1973).

It is concluded the peritrichous ciliates are more frequent ciliates causing mortality in cultured shrimps at high density in higher temperature and amonia compounds.

\section{References}

Abedian A. \& Ebrahimi M. (2006) Survey and identification of parasitic infections of cultured shrimp in Chabahar area, Iran. Iranian Fisheries Scientific Journal 15, 109-118.

Afsharnasab M. (2012) Rewiev of WSD in Iran (Past, Present, Future) and the effect on shrimp production Paper present in $17^{\text {th }}$ Iranian Veterinary Congress, Theran, Iran 28-30 Aprill.

Chakraborti J. \& Bandyapadhyay P. (2011) Seasonal incidence of protozoan parasites of the black tiger shrimp (\&lt;i\&gt;Penaeus monodon\&lt;/i\&gt;) of Sundarbans, West Bengal, India. Journal of Parasitic Diseases 35, 61-65.
Jalali Jafari B. (1990) Diseases of Cultured Shrimps, Tehran, Fisheries Org.

Jayasree L., Janakiram P. \& Madhavi R. (2001) Epibionts and parasites of Machrobrachium rosenbergii and Metapenaeus dobsoni from Gosthani estuary. Journal of Natural History 35, 157-167.

Johnson S.K. (1990) Handbook of Shrimp Diseases, Texas, Department of Wildlife and Fisheries Sciences, Texas A \& M University.

Kakoolaki S. (1997) Severe mortality in zoea of cultured Penaeus semisulcatus due to Zoothamnium sp. News letter of Iranian Fisheries Research Organization 18.

Kakoolaki S., Sharifpour I., Sharifrohani M., Ebrahimzadeh Mousavi H.A., Afsharnasab M., Hoghoughirad N., Dashtiannasab A. \& Nezamabadi H. (2013) Hemocytosis, a new disease in cultured shrimp, Fenneropenaeus indicus. Iranian Journal of Fisheries Sciences 12, 605-619.

Kakoolaki S., Soltani M., Ebrahimzadeh Mousavi H.A., Sharifpour I., Mirzargar S., Afsharnasab M. \& Motalebi A.A. (2011) The effect of different salinities on mortality and histopathological changes of SPF imported Litopenaeus vannamei, experimentally exposed to White Spot Virus and a new differential hemocyte staining method. Iranian Journal of Fisheries Sciences 10, 447-460.

Lightner D. (1996) A Handbook of Pathology and Diagnostic Procedures for Diseases of Penaeid Shrimp, LA, Baton Rouge, World Aquaculture Society.

Malolahi A. \& Mokhayer B. (2001) Survey on parasitic fauna of farmed shrimp in Ghofas area, Abadan in south of Iran. Tehran: IFRO.

Mayen-Estrada R. \& Aladro-Lubel M. A. (2002) Distribution and prevalence of 15 species of epibiont Peritrich ciliates on the crayfish Cambarellus patzcuarensis Villalobos, 1943 in lake Patzcuaro, Michoacan, Mexico. Crustaceana 74, 1213-1224.

Oie (2006) Manual of diagnostic for Aquatic Animals 
S Kakoolaki et al., Protozoan ectoparasite of white leg shrimp

[Online]. France: OIE. Available: http://www.oie.int/eng/ normes/fmanual/manual2006/A_00047.htm [Accessed 12.11.2010.

Overstreet R.M. (1973) Parasites of some penaeid shrimp with emphasis on reared hosts. Aquaculture 2, 105-140.

Tamjidi B. (1995) Isolation and Identification of the protozoa, zoothamnium sp. of cultured shrimp in Heleh farms, south of Iran. Iranian Fisheries Scientific Journal 4, 97-104. 


\title{
شيوع و شدت تك ياختههاى جلدى ميكو بِ سفيد سايت حله، جنوب ايران
}

\author{
شإيور كاكولكى '" محمد افشارنسب' \\ ابخش بهداشت و بيماريهاى آبزيان؛ سازمان تحقيقات، آموزش و ترويج كشاورزى، موسسه تحقيقات علوم شيلاتى كشور، يبكانشهر، سرو آزاد
}

توسـعه يرورش ميكو با بروز بيمارى هاى كشــنده از جمله ويروسى، باكتر يايى و تك ياختهاى انغل ميكو همر اه بوده است. مطالعه ما الرائه وضعيت

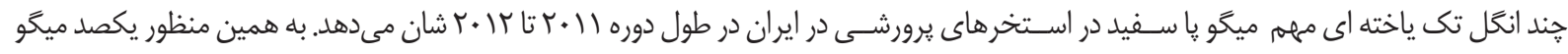

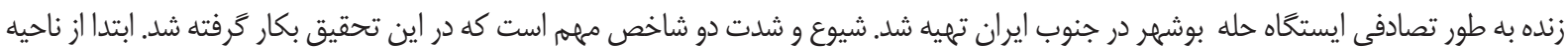

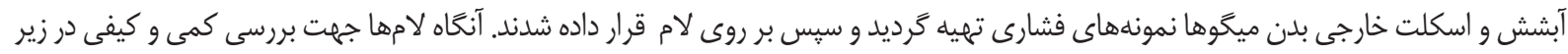

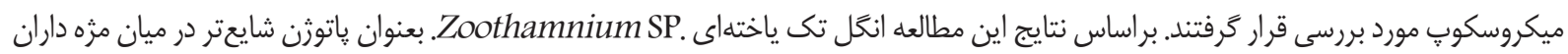

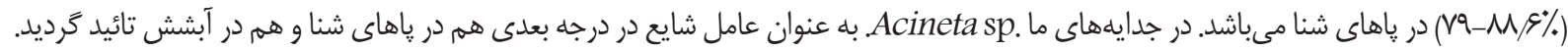

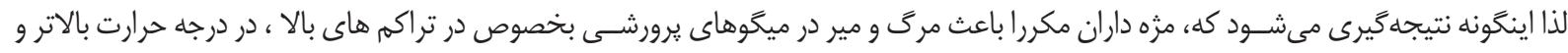

$$
\text { آمونياك بالا مىباشد. }
$$

وازههاى كليدى : ميخو، بيماريهاى انخلى، مثره دار، شيوع، شدت.

bsh443@gmail.com : : 